\title{
THE ANALYSIS OF BARRIERS TO BIM IMPLEMENTATION FOR INDUSTRIALIZED BUILDING CONSTRUCTION: A CHINA STUDY
}

\author{
Ping WU ${ }^{1,2}$, Ruoyu JIN ${ }^{{ }^{*}}{ }^{*}$, Yidong XU ${ }^{1,2}$, Feng $\mathrm{LIN}^{1,4}$, Yiting $\mathrm{DONG}^{1}$, Zhihong $\mathrm{PAN}^{4}$ \\ ${ }^{1}$ NingboTech University, 315100 Ningbo, China \\ ${ }^{2}$ Ningbo Research Institute, Zhejiang University, 315100 Ningbo, China \\ ${ }^{3}$ School of Built Environment and Architecture, London South Bank University, \\ 103 Borough Road, SE1 OAA London, UK \\ ${ }^{4}$ School of Civil Engineering and Architecture, Jiangsu University of Science and Technology, \\ Zhenjiang, 212003 Jiangsu, China
}

Received 14 July 2020; accepted 15 October 2020

\begin{abstract}
The emerging Building Information Modeling (BIM) can better promote the development of building industrialization, with data integration between information-rich building models and business processes. However, the practical implementation of BIM still faces barriers. Existing studies have discussed these barriers extensively, but the research on the barriers to the implementation of BIM amid building industrialization in China is inadequate. In this study, 23 barriers were identified through literature review. A questionnaire survey approach was used to collect data from various parties. Factor analysis methods were used to process and rank barrier factors for BIM applications in the context of industrialized building. Based on the analysis of each factor, analytic hierarchy process was adopted to identify the key barriers to the implementation of BIM for industrialized building construction. The study concluded that the main barriers for BIM implementation for industrialized building were capital-related factors and the lack of support from owners. This study proposes that in addition to governmental policy support for BIM and multi-stakeholder engagement, companies should also organize experts to effectively evaluate the risks of applying BIM. Overall, this study provides suggestions on construction organizational transformations in the roadmap of moving towards digital-driven building industrialization.
\end{abstract}

Keywords: industrialized building, building information modeling, prefabricated construction, China, barrier, Analytic hierarchy process, factor analysis, questionnaire survey.

\section{Introduction}

Since 1980, the productivity of construction industry worldwide has not been significantly enhanced. Compared to other industries, construction is still facing problems such as low profit margins and shortage of skilled workers (Babič et al., 2010). Low production efficiency directly leads to high costs (Wandahl \& Ussing, 2013). As the largest construction market worldwide (Li et al., 2017), China is facing the challenge of rising labor cost and sustainable development (He \& Chen, 2013). In addition, China's construction industry still has problems such as low production efficiency, large consumption of resources and energy, frequent safety accidents and environmental pollution (Zhang et al., 2016). Building industrialization, or off-site manufacturing of building construction, improves labor productivity by carrying out standardized design, factory production of structural components, and on-site assembly construction (Shen \& Li, 2015). It has become a key strategic direction for the construction industry to upgrade the traditional construction, and has attracted significant attention of the industry and governmental authorities at all levels (Wang et al., 2016).

BIM (Building Information Modeling) enables the construction industry to achieve informatization and efficient production through data integration between information-rich building models and business processes, thus promoting the development of off-site construction industrialization (Chan et al., 2019). In Europe, Japan, and Hong Kong SAR, BIM has been widely used in real estate development (Chunxia, 2011). However, there are still many factors hindering the implementation of BIM,

*Corresponding author. E-mails: jinruoyu@yahoo.com; jinr@lsbu.ac.uk 
such as cultural resistance, high investment costs, uncertainty about return on investment (ROI), participants unwilling to coordinate and lack of common BIM standards (Elmualim \& Gilder, 2014; Enshassi et al., 2016; Ismail et al., 2017; Mahalingam et al., 2015; Tan et al., 2019). Many researchers have proposed many valuable suggestions in solving these problems. Liu et al. (2015), Enshassi et al. (2016) and Ahmed (2018) believe that all stakeholders must work together to promote the development of BIM. Memon et al. (2014) proposed that providing trial software, training construction personnel, and introducing BIM in university courses are effective strategies to strengthen BIM implementation.

A review of these previous studies related to BIM and building industrialization revealed that: 1) limited studies have been performed in identifying the barriers to BIM implementation worldwide; 2) there have been limited studies focusing on how these barriers can be overcome in the context of building industrialization. This paper aims to explore the barriers towards BIM implementation amid building industrialization using Yangtze River Delta in China as the case. The objectives of this research include: 1) identifying barriers involved in BIM implementation for building industrialization; 2) analyzing the results obtained from questionnaire survey statistically; and 3) providing recommendations for overcoming obstacles. Based on the literature review and questionnaire survey method, 23 barriers towards BIM implementation were identified and analyzed. The key factors were determined by using analytic hierarchy process (AHP). Totally five countermeasures were proposed to address the above obstacles.

\section{Identification and classification of barrier factors}

In this study, the literature review started from keyword search in Scopus, Web of Science and Google Scholar, which are frequently used database with a wider coverage of journals and more recent publications (Xu et al., 2018). Keywords in the search of database included "building information modeling", "BIM", "industrialization", "prefabrication", "barrier", "obstacles", etc. The abstracts of each paper were read by the research team members in order to screen out relevant articles. Then, the barriers towards BIM implementation described in these articles were summarized and were divided into five categories, as shown in Table 1.

Table 1 provides the comprehensive evaluation of critical factors related to BIM implementation worldwide, such as organizational change and management support (Liao $\&$ Teo, 2019). The detailed evaluation of the literature listed in Table 1 is added to explain the five main factors and their sub-factors related to project stakeholders, financial investment, employees' uptake, external environment (e.g., legislation), software. These factors are not separated from each other, for example, functionalities of existing BIM software package would affect employee's uptake and ac- ceptance of BIM. The evaluation as reflected in Table 1 highlights BIM adoption in the context of prefabricated construction.

\section{Questionnaire survey and statistics}

\subsection{Questionnaire survey}

BIM adoption boosts standardization of architectural design, factory manufacturing of off-site components, construction and assembly, informationization of production and operation, and integration of construction project production. The questionnaire comprised of two main parts. The first part which was multiple choice focused on the professional background, as well as general opinions of survey participants coming from construction industry in the Yangtze River Delta of China. In the second part of the questionnaire, five-point Likert scale questions were initiated to measure barriers to BIM implementation in the context of building industrialization listed in Table 1. Through an online questionnaire survey, it is targeted to employees of companies in the construction field that use BIM technology and prefabricated buildings and totally 153 valid questionnaire responses were received. According to the information obtained through the questionnaire feedback is as follows, the background of the survey participants in this questionnaire survey, the designer accounted for $24.84 \%$, the construction accounted for $35.95 \%$, the owner accounted for $20.26 \%$, and the institution accounted for $24.84 \%$. Among the people surveyed, $67.32 \%$ of people have $0-5$ years of work experience, $22.22 \%$ of $5-10$ years, $4.58 \%$ of $10-15$ years, $5.88 \%$ higher than 15 years, as shown in Figure 1 and Figure 2.

\subsection{Statistical analysis}

Before the exploratory analysis, rationality analysis of the identified potential barrier factors was conducted by using Kaisor-Meyer-Olkin (KMO) and Bartlett's sphericity test, which determined whether the data met criteria for factor analysis. There is no uniform standard for the appropriate minimum value for the $\mathrm{KMO}$ to be considered acceptable. Its value varies from 0.50 to 0.70 (Ballantyne et al., 2011). According to Tabachnick et al. (2007), KMO value of 0.6 and above are considered good, and a value of 0.697 indicates that the factors extracted will account for a reasonable amount of variance. As shown in Table 2, the KMO value was 0.776 , and the significance of Bartlett's sphericity was $0.003\left(\chi^{2}=995, d f=324\right)$, indicating that the samples met the criteria for factor analysis.

To ensure that the feedback information is valid, further reliability estimate of data obtained from the questionnaire survey was conducted by adopting Cronbach's Alpha. As one of the most widely used measures of reliability in the social and organizational sciences, Cronbach's Alpha determines the internal consistency or average correlation of items in a survey instrument to gauge its reliability (Bonett \& Wright, 2015; Santos, 1999). 
Table 1. Identification and classification of potential barrier factors

\begin{tabular}{|c|c|c|c|}
\hline Primary factor & Sub-factor & References & Summary and evaluation \\
\hline \multirow[t]{7}{*}{$\begin{array}{l}\text { A: Project } \\
\text { stakeholder- } \\
\text { related factors }\end{array}$} & $\begin{array}{l}\text { A01: Lack of } \\
\text { support from senior } \\
\text { management }\end{array}$ & $\begin{array}{l}\text { Ahmed (2018); Arayici et al. (2011); Eadie } \\
\text { et al. (2014); Ganah and John (2015); Jung and } \\
\text { Joo (2011); Liu et al. (2015); Qinghua and Jing } \\
\text { (2012) }\end{array}$ & \multirow{7}{*}{$\begin{array}{l}\text { There has been a lack of guidelines } \\
\text { so far to standardize the process } \\
\text { of adopting BIM for industrialized } \\
\text { building projects. Specifically, different } \\
\text { stakeholders (e.g., clients, contractor, } \\
\text { architects, etc.) have not been able to } \\
\text { find the coordinated way of working } \\
\text { with each other crossing project stages. } \\
\text { The fear of changes brought by BIM } \\
\text { and prefabrication methods different } \\
\text { from the traditional site construction } \\
\text { delivery make stakeholders reluctant } \\
\text { to embrace them. The reluctance or } \\
\text { resistance of changes from companies' } \\
\text { senior management personnel causes } \\
\text { little progress in introducing BIM } \\
\text { into the organization, especially when } \\
\text { their experience and knowledge of } \\
\text { BIM is really limited. Even for those } \\
\text { organizations who have started } \\
\text { adopting BIM, different BIM authoring } \\
\text { tools or software packages bring } \\
\text { the challenges in data sharing and } \\
\text { information exchange. The lack of } \\
\text { legislation is also making stakeholders } \\
\text { concerned of the copyright and } \\
\text { ownership of data or models within } \\
\text { the digital assets. There is a need for } \\
\text { clearer definitions regarding the rights } \\
\text { and responsibilities in accessing and } \\
\text { using data. }\end{array}$} \\
\hline & $\begin{array}{l}\text { A02: Low level of } \\
\text { cooperation between } \\
\text { project participants } \\
\end{array}$ & $\begin{array}{l}\text { Ahmed (2018); von Both (2012); Chan et al. } \\
\text { (2019); Chunxia (2011); Kekana et al. (2014); } \\
\text { Newton and Chileshe (2012); Zhang et al. (2013) }\end{array}$ & \\
\hline & $\begin{array}{l}\text { A03: Lack of } \\
\text { experience in using } \\
\text { BIM }\end{array}$ & $\begin{array}{l}\text { Ahmed (2018); Kekana et al. (2014); } \\
\text { Khosrowshahi and Arayici (2012); Zhang et al. } \\
\text { (2013) }\end{array}$ & \\
\hline & $\begin{array}{l}\text { A04: Unclear } \\
\text { responsibilities for } \\
\text { BIM users }\end{array}$ & $\begin{array}{l}\text { Ahmed (2018); Azhar (2011); Chan (2014); } \\
\text { Eadie et al. (2014); Kekana et al. (2014); } \\
\text { Qinghua and Jing (2012); Zhang et al. (2013) }\end{array}$ & \\
\hline & $\begin{array}{l}\text { A05: Lack of } \\
\text { collaborative working } \\
\text { processes }\end{array}$ & Kekana et al. (2014); Liao et al. (2019) & \\
\hline & $\begin{array}{l}\text { A06: Reluctant to } \\
\text { share information } \\
\text { publicly for } \\
\text { stakeholders } \\
\end{array}$ & $\begin{array}{l}\text { Ahmed (2018); Kiviniemi et al. (2008); Qinghua } \\
\text { and Jing (2012); Zhang et al. (2013) }\end{array}$ & \\
\hline & $\begin{array}{l}\text { A07: Lack of demand } \\
\text { for BIM from clients }\end{array}$ & $\begin{array}{l}\text { Abubakar et al. (2014); Ahmed (2018); Ahmed } \\
\text { et al. (2014); Arayici et al. (2011); Chan (2014); } \\
\text { Enshassi and AbuHamra (2017); Hosseini et al. } \\
\text { (2016b); Jianxin (2010); Khosrowshahi and } \\
\text { Arayici (2012); Kiani et al. (2015); Matarneh and } \\
\text { Hamed (2017); Memon et al. (2014); Qinghua } \\
\text { and Jing (2012); Ullah et al. (2019) }\end{array}$ & \\
\hline \multirow[t]{3}{*}{$\begin{array}{l}\text { B: Financially- } \\
\text { related factors }\end{array}$} & $\begin{array}{l}\text { B01: High cost of } \\
\text { BIM software }\end{array}$ & $\begin{array}{l}\text { Abubakar et al. (2014); Ahmed (2018); Ahmed } \\
\text { et al. (2014); Azhar (2011); Chan (2014); Crotty } \\
\text { (2013); Eadie et al. (2014); Gerges et al. (2017); } \\
\text { Hosseini et al. (2016a); Ismail et al. (2017); } \\
\text { Khosrowshahi and Arayici (2012); Kiani et al. } \\
\text { (2015); Kiviniemi et al. (2008); Liu et al. (2015); } \\
\text { Matarneh and Hamed (2017); Memon et al. } \\
\text { (2014); Newton and Chileshe (2012); Qinghua } \\
\text { and Jing (2012); Stanley and Thurnell (2014); } \\
\text { Thompson and Miner (2006); Yan and Demian } \\
\text { (2008); Zhang et al. (2013) }\end{array}$ & \multirow[t]{3}{*}{$\begin{array}{l}\text { Although with promising returns } \\
\text { of investment in adopting BIM, the } \\
\text { short-term higher costs (e.g., BIM } \\
\text { software investment) could cause } \\
\text { financial burdens especially for small } \\
\text { and medium-sized enterprises. Part } \\
\text { of industry professionals perceive the } \\
\text { investment could not be recovered by } \\
\text { return, which is measured by tangible } \\
\text { and intangible benefits brought by } \\
\text { BIM, such as reduced design errors, } \\
\text { increased productivity, and enhanced } \\
\text { company images for marketing, etc. }\end{array}$} \\
\hline & $\begin{array}{l}\text { B02: High risk of } \\
\text { ROI }\end{array}$ & $\begin{array}{l}\text { Ahmed (2018); Eadie et al. (2014); Tan et al. } \\
\text { (2019); Ullah et al. (2019) }\end{array}$ & \\
\hline & $\begin{array}{l}\text { B03: Lack of benefits } \\
\text { brought by BIM }\end{array}$ & $\begin{array}{l}\text { Abubakar et al. (2014); Ahmed (2018); } \\
\text { Elmualim and Gilder (2014); Hosseini et al. } \\
\text { (2016a); Zhang et al. (2013) }\end{array}$ & \\
\hline \multirow[t]{3}{*}{$\begin{array}{l}\text { C: Employee- } \\
\text { related factors }\end{array}$} & $\begin{array}{l}\text { C01: Lack of talents } \\
\text { with relevant skills } \\
\text { and knowledge }\end{array}$ & $\begin{array}{l}\text { Abubakar et al. (2014); Ahmed (2018); Arayici } \\
\text { et al. (2011); von Both (2012); Chan (2014); } \\
\text { Chunxia (2011); Enshassi and AbuHamra } \\
\text { (2017); Gerges et al. (2017); Gerrard et al. } \\
\text { (2010); Hosseini et al. (2016a); Kiani et al. } \\
\text { (2015); Liu et al. (2015); Matarneh and Hamed } \\
\text { (2017); Memon et al. (2014); Newton and } \\
\text { Chileshe (2012); Wang et al. (2016) }\end{array}$ & \multirow{3}{*}{$\begin{array}{l}\text { Technological advancement cannot be } \\
\text { achieved without skilled employees } \\
\text { who can adopt and promote BIM. } \\
\text { For those who are new to BIM, the } \\
\text { learning curve and uptake process } \\
\text { can be time-consuming creating } \\
\text { extra burden and costing resources } \\
\text { to employees. As a result, employees' } \\
\text { motivation may not be maintained } \\
\text { high. Current BIM education and } \\
\text { training have been focusing more on } \\
\text { specialized software operation, but } \\
\text { have not been sufficiently reaching the } \\
\text { project-based applications. }\end{array}$} \\
\hline & $\begin{array}{l}\text { C02: Slow uptake } \\
\text { of BIM-related } \\
\text { technologies } \\
\end{array}$ & Ahmed (2018); Chunxia (2011) & \\
\hline & $\begin{array}{l}\text { C03: Unavailability } \\
\text { of proper training } \\
\text { on BIM }\end{array}$ & $\begin{array}{l}\text { Ahmed (2018); Chan (2014); Chan et al. (2019); } \\
\text { Eadie et al. (2014); Enshassi and AbuHamra } \\
\text { (2017); Gerrard et al. (2010); Kiani et al. (2015); } \\
\text { Matarneh and Hamed (2017); Newton and } \\
\text { Chileshe (2012); Park and Kim (2017) }\end{array}$ & \\
\hline
\end{tabular}


End of Table 1

\begin{tabular}{|c|c|c|c|}
\hline Primary factor & Sub-factor & References & Summary and evaluation \\
\hline \multirow[t]{4}{*}{$\begin{array}{l}\text { D: Factors } \\
\text { related to } \\
\text { external } \\
\text { environment }\end{array}$} & $\begin{array}{l}\text { D01: Insufficient } \\
\text { legislation and } \\
\text { regulations }\end{array}$ & $\begin{array}{l}\text { Abubakar et al. (2014); Ahmed (2018); Azhar } \\
\text { (2011); Eadie et al. (2014); Enshassi and } \\
\text { AbuHamra (2017); Gerrard et al. (2010); Jianxin } \\
\text { (2010); Kekana et al. (2014); Kiani et al. (2015); } \\
\text { Li and Yang (2017); Qinghua and Jing (2012); } \\
\text { Stanley and Thurnell (2014); Ullah et al. (2019); } \\
\text { Zhang et al. (2013) }\end{array}$ & \multirow{4}{*}{$\begin{array}{l}\text { There has not been sufficient BIM } \\
\text { practical experience in the context } \\
\text { of prefabricated construction. } \\
\text { Stakeholders expect the existing } \\
\text { experience of BIM adoption in projects } \\
\text { and established standards for their } \\
\text { own project delivery. However, the } \\
\text { inadequate standards, legislation, and } \\
\text { guidelines especially integrating BIM } \\
\text { for prefabricated construction make } \\
\text { stakeholders and their organizations } \\
\text { challenging in the transformation } \\
\text { towards digital-driven industrialization } \\
\text { in construction. }\end{array}$} \\
\hline & $\begin{array}{l}\text { D02: Weak } \\
\text { theoretical } \\
\text { foundation } \\
\end{array}$ & $\begin{array}{l}\text { Ahmed (2018); Chunxia (2011); Matarneh and } \\
\text { Hamed (2017); Zhang et al. (2013) }\end{array}$ & \\
\hline & $\begin{array}{l}\text { D03: Lack of } \\
\text { standards to guide } \\
\text { implementation }\end{array}$ & $\begin{array}{l}\text { Abubakar et al. (2014); Ahmed (2018); von Both } \\
\text { (2012); Chan (2014); Chan et al. (2019); Kekana } \\
\text { et al. (2014); Kiviniemi et al. (2008); Li and Yang } \\
\text { (2017); Liu et al. (2015); Matarneh and Hamed } \\
\text { (2017); Qinghua and Jing (2012); Stanley and } \\
\text { Thurnell (2014); Tan et al. (2019); Ullah et al. } \\
\text { (2019); Zhang et al. (2013) }\end{array}$ & \\
\hline & $\begin{array}{l}\text { D04: Organizations } \\
\text { not supporting the } \\
\text { use of BIM due to } \\
\text { cultural resistance }\end{array}$ & $\begin{array}{l}\text { Chan et al. (2019); Czmoch and Pękala (2014); } \\
\text { Hope and Alwan (2012); Hosseini et al. (2016a); } \\
\text { Won and Lee (2010); Wong et al. (2009) }\end{array}$ & \\
\hline \multirow[t]{6}{*}{$\begin{array}{l}\text { E: Software- } \\
\text { related factors }\end{array}$} & $\begin{array}{l}\text { E01: Lack of } \\
\text { domestic-oriented } \\
\text { BIM tools }\end{array}$ & $\begin{array}{l}\text { Chunxia (2011); He et al. (2012); Li and Yang } \\
\text { (2017); Pan and Zhao (2012); Tan et al. (2019); } \\
\text { Zhang et al. (2013) }\end{array}$ & \multirow{5}{*}{$\begin{array}{l}\text { BIM authoring software tools are } \\
\text { an important part of construction } \\
\text { industry's digitalization path. Various } \\
\text { issues related to software tools are } \\
\text { causing barriers, e.g., different software } \\
\text { tools in the market causing data and } \\
\text { information uninterpretable among } \\
\text { project partners. International software } \\
\text { package has to be adapted in the } \\
\text { local industry context. The currently } \\
\text { localized software tools cannot } \\
\text { fully meet the project needs such as } \\
\text { functionalities in the digital library of } \\
\text { modularized building components. } \\
\text { Rule-checking following the local } \\
\text { industry regulations and codes is } \\
\text { also an issue by using existing BIM } \\
\text { author tools. Available BIM software } \\
\text { tools may turn out more challenging } \\
\text { for employees to adopt (e.g., user- } \\
\text { friendliness) compared to the software } \\
\text { package in the pre-BIM era. }\end{array}$} \\
\hline & $\begin{array}{l}\text { E02: Poor user } \\
\text { experience for } \\
\text { software developed } \\
\text { abroad } \\
\end{array}$ & Chunxia (2011); B. Liu and W. Liu (2015) & \\
\hline & $\begin{array}{l}\text { E03: Complexity } \\
\text { of existing BIM } \\
\text { software }\end{array}$ & $\begin{array}{l}\text { Ahmed et al. (2014); von Both (2012); Chan } \\
\text { (2014); Jianxin (2010); Qinghua and Jing (2012); } \\
\text { Stanley and Thurnell (2014); Ullah et al. (2019) }\end{array}$ & \\
\hline & $\begin{array}{l}\text { E04: Poor } \\
\text { interoperability of } \\
\text { BIM software tools }\end{array}$ & $\begin{array}{l}\text { von Both (2012); Chan (2014); Elagiry et al. } \\
\text { (2019); Enshassi and AbuHamra (2017); Gerrard } \\
\text { et al. (2010); Hosseini et al. (2016b); Jianxin } \\
\text { (2010); Jordani (2010); Kekana et al. (2014); } \\
\text { Kiviniemi et al. (2008); Migilinskas et al. (2013); } \\
\text { Newton and Chileshe (2012); Park and Kim } \\
\text { (2017); Qinghua and Jing (2012); Stanley and } \\
\text { Thurnell (2014); Ullah et al. (2019) }\end{array}$ & \\
\hline & $\begin{array}{l}\text { E05: Poor security } \\
\text { performance of BIM }\end{array}$ & Zhang et al. (2013) & \\
\hline & $\begin{array}{l}\text { E06: Incomplete } \\
\text { modeling functions } \\
\text { in BIM software } \\
\text { tools }\end{array}$ & von Both (2012); Zhang et al. (2013) & \\
\hline
\end{tabular}

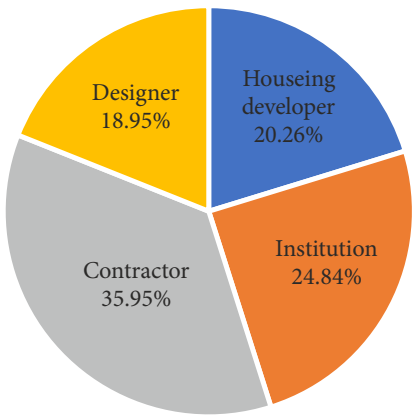

Figure 1. Specific fields of work

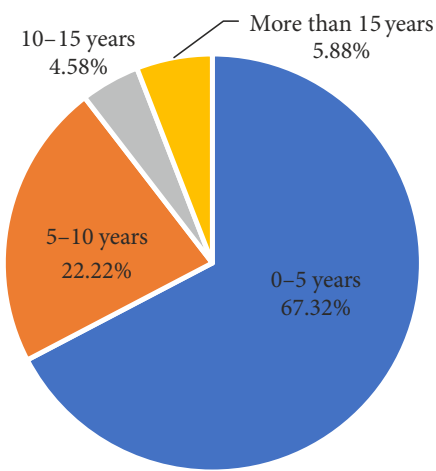

Figure 2. Working experience 
Table 2. KMO and Bartlett's tests

\begin{tabular}{|l|c|c|}
\hline \multicolumn{2}{|l|}{ Kaiser-Meyer-Olkin measure of sampling sufficiency } & 0.776 \\
\hline $\begin{array}{l}\text { Bartlett's } \\
\text { sphericity test }\end{array}$ & Approximate chi-square & 995.318 \\
\cline { 2 - 3 } & df & 324 \\
\cline { 2 - 3 } & Sig. & 0.003 \\
\hline
\end{tabular}

The value of Cronbach's Alpha expressed as a numerical value between 0 and 1 . The closer the coefficient is to 1.0, the greater the internal consistency of the items would be, as shown in Table 3 (Namdeo \& Rout, 2016). Cronbach 's Alpha coefficient of this questionnaire was calculated by using SPSS. The value is 0.906 which indicates that the questionnaire design is excellent.

\section{Results and discussion}

\subsection{Identification of key barriers based on factor analysis}

The date collected from the questionnaire was analyzed by using SPSS software. The mean value, standard deviation, variance and skewness are shown in Table 4. Figure 3 shows the mean value of factors that hinder the implementation of BIM in the context of building industrialization. The factors with a mean value greater than 3.9 were selected for analysis.

\section{1) A01: Lack of support from senior management}

The support from senior management in the construction industry not only refers to the support from the leaders of the company and project, but also includes the support from the owner. Although the support of organizational senior management is important, it will be greatly affected in terms of funding from the owner. The development and application of BIM in the project will be greatly affected if the owner's support is lacking. According to the information collected from the questionnaire survey, most respondents agreed that the support of senior leaders is critical to the implementation of BIM in building industrialization. As shown in Table 5, the lack of support from senior management has been ranked as very important by $34.64 \%$ of the respondents, and only a small number of respondents $(1.96 \%)$ believe that the lack of support from senior management is not important.

Table 3. The scales of Cronbach's Alpha coefficient for reliability estimate

\begin{tabular}{|c|c|c|c|c|c|c|}
\hline Cronbach's Alpha & {$[0,0.5)$} & {$[0.5,0.6)$} & {$[0.6,0.7)$} & {$[0.7,0.8)$} & {$[0.8,0.9)$} & {$[0.9,1]$} \\
\hline Reliability estimate & Unacceptable & Poor & Questionable & Acceptable & Good & Excellent \\
\hline
\end{tabular}

Table 4. Statistical analysis of factors that hinder the application of BIM for building industrialization

\begin{tabular}{|c|c|c|c|c|c|}
\hline Category & Barrier & $\begin{array}{l}\text { Mean } \\
\text { value }\end{array}$ & $\begin{array}{l}\text { Standard } \\
\text { deviation }\end{array}$ & Variance & Skewness \\
\hline \multirow{7}{*}{$\begin{array}{l}\text { A: Project } \\
\text { stakeholder-related }\end{array}$} & A01: Lack of support from senior management & 4.03 & 0.93 & 0.87 & -0.94 \\
\hline & A02: Low level of cooperation between project participants & 3.8 & 0.86 & 0.75 & -0.35 \\
\hline & A03: Lack of experience in using BIM & 4 & 0.93 & 0.86 & -0.54 \\
\hline & A04: Unclear responsibilities for BIM users & 3.83 & 0.92 & 0.85 & -0.47 \\
\hline & A05: Lack of collaborative working processes & 3.84 & 0.93 & 0.86 & -0.52 \\
\hline & A06: Reluctant to share information publicly for participants & 3.86 & 0.94 & 0.88 & -0.4 \\
\hline & A07: Owner lacks of demand for BIM & 3.81 & 1.1 & 1.1 & -0.6 \\
\hline \multirow[t]{3}{*}{ B: Financially-related } & B01: High cost of BIM software & 3.92 & 0.91 & 0.84 & -0.63 \\
\hline & B02: High risk of ROI & 3.82 & 0.84 & 0.72 & -0.37 \\
\hline & B03: Lack of benefits brought by BIM & 3.92 & 0.91 & 0.84 & -0.4 \\
\hline \multirow[t]{3}{*}{ C: Employee-related } & C01: Lack of talent with relevant skills and knowledge & 3.9 & 0.88 & 0.77 & -0.39 \\
\hline & C02: Slow learning of BIM-related technologies & 3.71 & 0.86 & 0.75 & -0.32 \\
\hline & C03: Unavailability of proper training on BIM & 3.75 & 0.92 & 0.86 & -0.11 \\
\hline \multirow{4}{*}{$\begin{array}{l}\text { D: Related to the } \\
\text { external environment }\end{array}$} & D01: Relevant laws and regulations are not perfect & 3.79 & 0.87 & 0.76 & -0.06 \\
\hline & D02: Weak theoretical foundation & 3.6 & 0.89 & 0.79 & -0.08 \\
\hline & D03: Lack of standards to guide implementation & 3.76 & 0.88 & 0.78 & -0.05 \\
\hline & D04: Organizations do not support the use of BIM due to habits & 3.79 & 0.82 & 0.7 & -0.16 \\
\hline \multirow[t]{6}{*}{ E: Related to software } & E01: Lack of domestic-oriented BIM tools & 3.79 & 0.85 & 0.72 & -0.44 \\
\hline & E02: Poor user experience for software developed abroad & 3.56 & 0.94 & 0.89 & -0.51 \\
\hline & E03: Complexity of existing BIM software & 3.73 & 0.92 & 0.85 & -0.35 \\
\hline & \begin{tabular}{|l|} 
E04: Poor interoperability of BIM software \\
\end{tabular} & 3.76 & 0.9 & 0.82 & -0.42 \\
\hline & E05: Poor security performance of BIM & 3.58 & 0.94 & 0.9 & -0.36 \\
\hline & E06: Incomplete modeling functions in BIM software & 3.8 & 1.0 & 1.0 & -0.51 \\
\hline
\end{tabular}




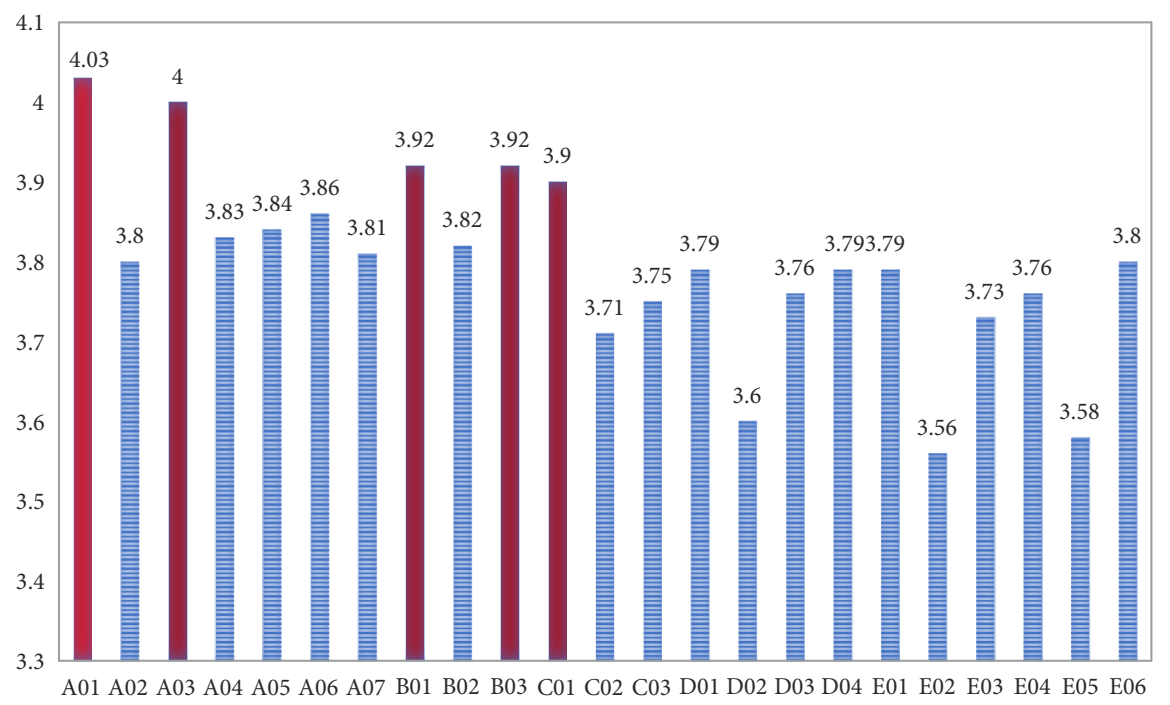

Figure 3. Mean value of factors that hinder the implementation of BIM in the background of building industrialization

Table 5. Statistics table on the importance of lack of support from senior management

\begin{tabular}{|l|c|c|}
\hline $\begin{array}{c}\text { Lack of support from } \\
\text { senior management }\end{array}$ & $\begin{array}{c}\text { number of } \\
\text { respondents }\end{array}$ & Percentage \\
\hline Not important & 3 & $1.96 \%$ \\
\hline Can be ignored & 6 & $3.92 \%$ \\
\hline Somehow important & 28 & $18.3 \%$ \\
\hline Important & 63 & $41.18 \%$ \\
\hline Very important & 53 & $34.64 \%$ \\
\hline
\end{tabular}

In this survey, $15.69 \%$ of the respondents indicated that the level of BIM in their organization is very low, 20.26\% of the respondents indicated that the level of BIM is relatively low, and $39.22 \%$ of the respondents indicated that the level of BIM technology in company is high, $22.22 \%$ of the respondents indicated that the level of BIM technology is relatively high, and only $2.61 \%$ of the respondents indicated that the level of BIM technology in their company is very high, as shown in Figure 4. Obviously, the implementation of BIM without senior management support is one main reason for the obstacles to the application of BIM.

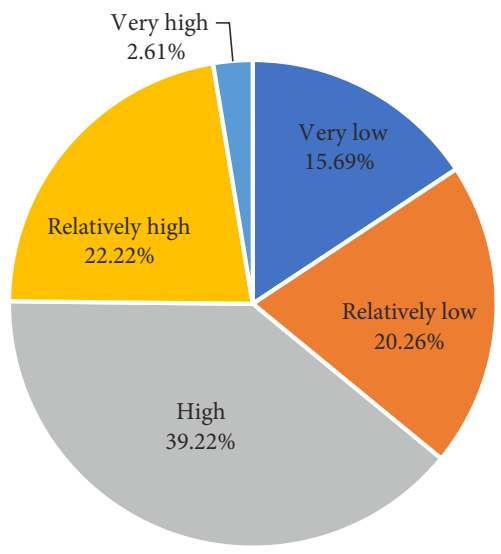

Figure 4. statistical chart of implementation degree of BIM in respondents' companies

\section{2) A03: Lack of experience in adopting BIM}

Among the information collected from the questionnaire survey, most respondents recognized the importance of BIM implementation experience. In this survey, $36.6 \%$ of respondents perceived that experience is very important in the application of BIM, and only $0.65 \%$ of the respondents believe that lack of experience is not important for the application of BIM technology, as shown in Table 6.

In this survey, $26.8 \%$ of the respondents claimed that they had never deployed BIM at work, $20.26 \%$ of the respondents said that they occasionally used BIM at work,

Table 6. Statistics table on the importance of the lack of experience in using BIM in the project

\begin{tabular}{|l|c|c|}
\hline \multicolumn{1}{|c|}{$\begin{array}{c}\text { Lack of experience in } \\
\text { using BIM }\end{array}$} & $\begin{array}{c}\text { Number of } \\
\text { respondents }\end{array}$ & Percentage \\
\hline Not important & 1 & $0.65 \%$ \\
\hline Can be ignored & 7 & $4.58 \%$ \\
\hline A little important & 39 & $25.49 \%$ \\
\hline Important & 50 & $32.68 \%$ \\
\hline Very important & 56 & $36.6 \%$ \\
\hline
\end{tabular}

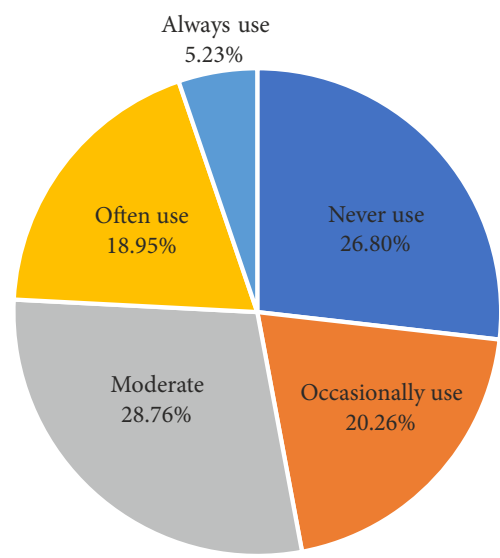

Figure 5. Statistical chart of BIM application degree of respondents 
and $28.76 \%$ of the respondents said that the use of BIM technology at work was moderate. $18.95 \%$ of the respondents indicated that they often use BIM technology in their work, and only $5.23 \%$ of the respondents indicated that they always use BIM technology in their work, as shown in Figure 5. Therefore, the government needs to guide related industries, actively promote the use of BIM technology in engineering projects, increase the BIM application rate, and enhance the experience of various companies in the construction industry using BIM in projects.

\section{3) B01: High cost of BIM software}

It can be seen from the information collected from the questionnaire survey that the high cost of BIM software is also the main reason that affects the application of BIM technology. Among them, 29.41\% of the respondents think that software costs are very critical, and those who think that software costs are not important account for only $1.31 \%$, as shown in Table 7 .

Table 7. Statistical table of the importance of the high cost of BIM software

\begin{tabular}{|l|c|c|}
\hline \multicolumn{1}{|c|}{$\begin{array}{c}\text { High cost of BIM } \\
\text { software }\end{array}$} & $\begin{array}{c}\text { Number of } \\
\text { respondents }\end{array}$ & Percentage \\
\hline Not important & 2 & $1.31 \%$ \\
\hline Can be ignored & 7 & $4.58 \%$ \\
\hline A little important & 37 & $24.18 \%$ \\
\hline Important & 62 & $40.52 \%$ \\
\hline Very important & 45 & $29.41 \%$ \\
\hline
\end{tabular}

The investment cost of BIM software is indispensable for a project. The high costs of software purchase and later maintenance costs cause the high cost of BIM software, which hinders the application of BIM technology in the background of building industrialization. According to the survey, the proportion of software purchase expenses from 0 to $50,000 \mathrm{RMB}$ is $35.95 \%$, the proportion of software purchase expenses from 50,000 to $100,000 \mathrm{RMB}$ is $28.1 \%$, the proportion of software purchase expenses from 100,000 to $150,000 \mathrm{RMB}$ is $24.84 \%$, and the proportion of software which costs more than $150,000 \mathrm{RMB}$ is $11.11 \%$, as shown in Figure 6.

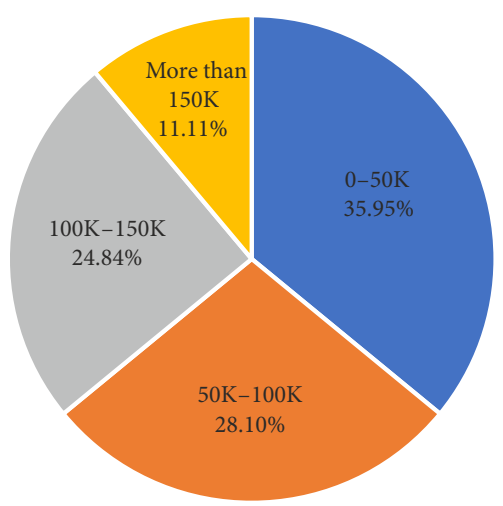

Figure 6. Statistics chart of BIM Software Purchase Expenses
From the above analysis, it is seen that the return on investment of the project using BIM is lower than the benchmarked return, which causes the application obstacles of BIM. Therefore, the cooperation and communication with BIM software development enterprises and BIM consulting companies can be strengthened to reduce the later maintenance cost of the software, thus promoting the application of BIM Technology in the building industrialization.

\section{4) B03: Lack of benefits brought by BIM}

It can be seen from the feedback data that the benefits brought by BIM technology are also important factors affecting the application of BIM technology. In this survey, it can be found that $66.02 \%$ of respondents believe that the actual benefits brought by BIM technology are important or very important, while only $0.65 \%$ of the respondents consider the actual benefits brought by BIM technology are not important. as shown in Table 8.

Table 8. Statistics table on the importance of the actual benefits brought by BIM technology

\begin{tabular}{|l|c|c|}
\hline $\begin{array}{c}\text { The benefits brought } \\
\text { by BIM technology }\end{array}$ & Employee-related & Percentage \\
\hline Not important & 1 & $0.65 \%$ \\
\hline Can be ignored & 7 & $4.58 \%$ \\
\hline A little important & 44 & $28.76 \%$ \\
\hline Important & 52 & $33.99 \%$ \\
\hline Very important & 49 & $32.03 \%$ \\
\hline
\end{tabular}

Judging from some current projects, the cost of using BIM technology is still relatively high. From the survey report, it is concluded that the proportion of companies whose cost of BIM technology training is from 0 to 50,000 is $38.56 \%$, the proportion of companies whose cost of BIM technology training is from 50,000 to 100,000 is $39.71 \%$, the proportion of companies whose cost of BIM technology training is from 100,000 to 150,000 is $16.34 \%$, and the proportion of companies whose cost of BIM technology training is more than 150,000 is $7.19 \%$, as shown in Figure 7.

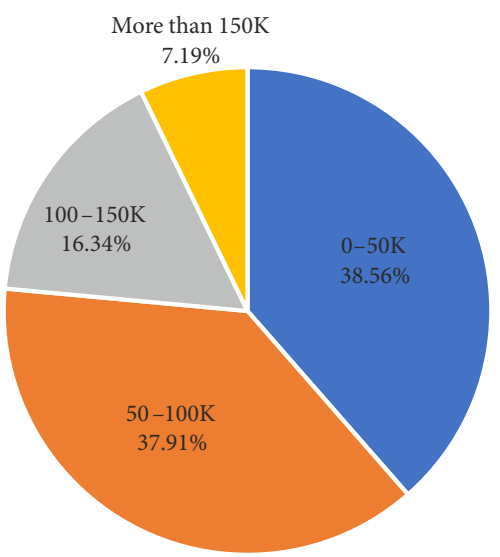

Figure 7. Statistics chart of the amount of BIM technical training expenses per company 
Obviously, the use of BIM technology increases costs. The lack of actual benefits brought by BIM application is the main reason why many companies are unwilling to form their own BIM teams. Therefore, the lack of practical benefits brought by BIM will affect the application of BIM in the background of building industrialization, and it is necessary to continuously improve and establish a reasonable mechanism to solve this problem.

\section{5) C01: Lack of talent with relevant skills and knowledge}

It can be seen from the feedback data that lack of skilled personnel is one of the important factors affecting the application of BIM. It can be found in this survey that $28.1 \%$ of the respondents consider the lack of talents with relevant skills and knowledge very important, and only $0.65 \%$ of the respondents think that the importance is very low, as shown in Table 9.

Table 9. Statistics table on the importance of lack of relevant skills and knowledge

\begin{tabular}{|l|c|c|}
\hline \multicolumn{1}{|c|}{$\begin{array}{c}\text { Lack of skilled } \\
\text { personnel }\end{array}$} & $\begin{array}{c}\text { Number of } \\
\text { people }\end{array}$ & Percentage \\
\hline Not important & 1 & $0.65 \%$ \\
\hline Can be ignored & 6 & $3.92 \%$ \\
\hline A little important & 43 & $28.1 \%$ \\
\hline Important & 60 & $39.22 \%$ \\
\hline Very important & 43 & $28.1 \%$ \\
\hline
\end{tabular}

In the background of the rapid development of the construction industry today, enterprises need not only the technical support, but also talents. However, due to the lack of BIM technical talents, many companies choose to train their own BIM technical talents, as shown in Figure 8.

Skilled employees are critical for an enterprise, and the cultivation of BIM technology-related talent is an important factor affecting the depth and breadth of BIM technology development. Due to the relative lack of relevant

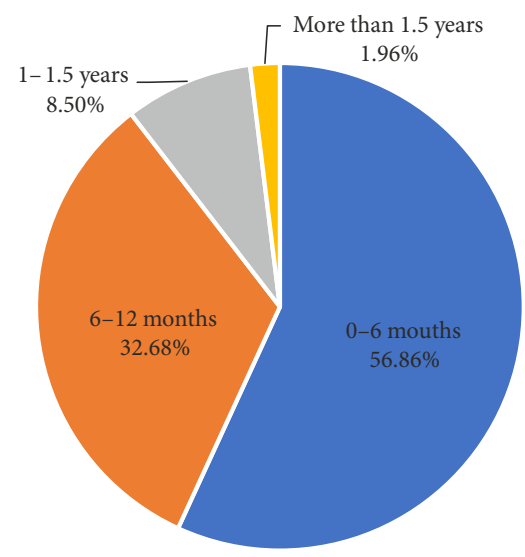

Figure 8. Statistics chart of training time of BIM technicians by enterprises talents, there is a shortage of talents with relevant skills and knowledge when enterprises apply BIM technology. Therefore, in order to promote the development of BIM, the first issue is the lack of BIM-skilled employees. The measures taken by some provincial and municipal governments can also be considered as ways to promote the training of BIM talents. For example, in Shanghai, if the project uses BIM from design to construction, the government will give a fairly high subsidy, which will promote the owner or construction companies use BIM technology and cultivate BIM talents; back in 2018, it was highlighted by the Central Governmental Authority that colleges and universities are the main force for training BIM talents. Therefore, the higher education sector of many provinces and cities have actively promoted the BIM skill training courses based on core specialized courses in colleges and universities which have the foundation of various majors in architecture, engineering, and construction.

\subsection{Ranking the barriers based on AHP}

Based on the analysis of various factors, the analytic hierarchy process is used to analyze the barriers to the application of BIM in the background of building industrialization. A total of 12 experts were consulted to determine the relative importance of each factor. The sample size of expert group in this study for conducting AHP was considered reasonable following the methodological guide from previous studies (Thanki et al., 2016). These experts came from BIM-specialized research and development, or construction engineering professions, and were recognized with senior-level of professional experience (e.g., with more than ten years of full-time relevant experience). The hierarchical analysis results of each factor are shown in Table 10, the average random consistency index is displayed in Table 11, and the ranking results of barrier factors are summarized in Table 12.

Table 10. AHP analytic results

\begin{tabular}{|c|c|c|c|c|}
\hline \multicolumn{5}{|c|}{ AHP analytic results } \\
\hline Items & Eigenvector & $\begin{array}{l}\text { Weighted } \\
\text { value }\end{array}$ & $\begin{array}{c}\text { Eigenvalue } \\
\text { of maximum }\end{array}$ & $\begin{array}{c}\mathrm{CI} \\
\text { value }\end{array}$ \\
\hline $\begin{array}{l}\text { Project } \\
\text { stakeholder- } \\
\text { related }\end{array}$ & 1.309 & $26.179 \%$ & \multirow{5}{*}{5.068} & \multirow{5}{*}{0.017} \\
\hline $\begin{array}{l}\text { Financially- } \\
\text { related }\end{array}$ & 2.081 & $41.621 \%$ & & \\
\hline $\begin{array}{l}\text { Employee- } \\
\text { related }\end{array}$ & 0.805 & $16.105 \%$ & & \\
\hline $\begin{array}{l}\text { Related to } \\
\text { the external } \\
\text { environment }\end{array}$ & 0.493 & $9.857 \%$ & & \\
\hline $\begin{array}{l}\text { Related to } \\
\text { software }\end{array}$ & 0.312 & $6.238 \%$ & & \\
\hline
\end{tabular}


Table 11. Mean random consistency index

\begin{tabular}{|c|c|c|c|c|c|c|c|c|c|c|}
\hline \multicolumn{10}{|c|}{ Mean random consistency index } \\
\hline 1 & 2 & 3 & 4 & 5 & 6 & 7 & 8 & 9 & 10 & 11 \\
\hline 0.00 & 0.00 & 0.58 & 0.90 & 1.12 & 1.24 & 1.32 & 1.41 & 1.45 & 1.49 & 1.51 \\
\hline
\end{tabular}

Table 12. Analysis of influence factors of barrier factors

\begin{tabular}{|c|c|c|c|c|c|c|c|}
\hline Sub-factors & $\begin{array}{l}\text { A: } \\
\text { Project } \\
\text { stakeholder- } \\
\text { related } \\
0.26\end{array}$ & $\begin{array}{c}\text { B: } \\
\text { Financially- } \\
\text { related } \\
0.42\end{array}$ & $\begin{array}{c}\text { C: } \\
\text { Employee- } \\
\text { related } \\
0.16\end{array}$ & $\begin{array}{c}\text { D: } \\
\text { Related to } \\
\text { the external } \\
\text { environment } \\
0.1\end{array}$ & $\begin{array}{c}\text { E: } \\
\text { Related to } \\
\text { software } \\
0.06\end{array}$ & $\begin{array}{c}\text { Influence } \\
\text { degree }\end{array}$ & $\begin{array}{l}\text { Influence } \\
\text { degree } \\
\text { ranking }\end{array}$ \\
\hline $\begin{array}{l}\text { A01: Lack of support from senior } \\
\text { management }\end{array}$ & 0.32 & & & & & 0.0832 & 5 \\
\hline $\begin{array}{l}\text { A02: Low level of cooperation between } \\
\text { project participants }\end{array}$ & 0.21 & & & & & 0.0546 & 6 \\
\hline A03: Lack of experience in using BIM & 0.14 & & & & & 0.0364 & 9 \\
\hline $\begin{array}{l}\text { A04: Unclear responsibilities for BIM } \\
\text { users }\end{array}$ & 0.09 & & & & & 0.0234 & 13 \\
\hline $\begin{array}{l}\text { A05: Lack of collaborative working } \\
\text { processes }\end{array}$ & 0.08 & & & & & 0.0208 & 14 \\
\hline $\begin{array}{l}\text { A06: Reluctant to share information } \\
\text { publicly for participants }\end{array}$ & 0.06 & & & & & 0.0156 & 17 \\
\hline A07: Owner lacks of demand for BIM & 0.1 & & & & & 0.026 & 11 \\
\hline B01: High cost of BIM software & & 0.4 & & & & 0.168 & 1 \\
\hline B02: High risk of ROI & & 0.2 & & & & 0.084 & 4 \\
\hline B03: Lack of benefits brought by BIM & & 0.4 & & & & 0.168 & 1 \\
\hline $\begin{array}{l}\text { C01: Lack of talent with relevant skills } \\
\text { and knowledge }\end{array}$ & & & 0.54 & & & 0.0864 & 3 \\
\hline $\begin{array}{l}\text { C02: Slow learning of BIM-related } \\
\text { technologies }\end{array}$ & & & 0.16 & & & 0.0256 & 12 \\
\hline $\begin{array}{l}\text { C03: Unavailability of proper training } \\
\text { on BIM }\end{array}$ & & & 0.3 & & & 0.048 & 7 \\
\hline $\begin{array}{l}\text { D01: Relevant laws and regulations are } \\
\text { not perfect }\end{array}$ & & & & 0.37 & & 0.037 & 8 \\
\hline D02: Weak theoretical foundation & & & & 0.1 & & 0.01 & 20 \\
\hline $\begin{array}{l}\text { D03: Lack of standards to guide } \\
\text { implementation }\end{array}$ & & & & 0.19 & & 0.019 & 16 \\
\hline $\begin{array}{l}\text { D04: Organizations do not support the } \\
\text { use of BIM due to habits }\end{array}$ & & & & 0.34 & & 0.034 & 10 \\
\hline $\begin{array}{l}\text { E01: Lack of domestic-oriented BIM } \\
\text { tools }\end{array}$ & & & & & 0.25 & 0.015 & 18 \\
\hline $\begin{array}{l}\text { E02: Poor user experience for software } \\
\text { developed abroad }\end{array}$ & & & & & 0.05 & 0.003 & 23 \\
\hline $\begin{array}{l}\text { E03: Complexity of existing BIM } \\
\text { software }\end{array}$ & & & & & 0.12 & 0.0072 & 21 \\
\hline $\begin{array}{l}\text { E04: Poor interoperability of BIM } \\
\text { software }\end{array}$ & & & & & 0.17 & 0.0102 & 19 \\
\hline E05: Poor security performance of BIM & & & & & 0.07 & 0.0042 & 22 \\
\hline $\begin{array}{l}\text { E06: Incomplete modeling functions in } \\
\text { BIM software }\end{array}$ & & & & & 0.34 & 0.0204 & 15 \\
\hline
\end{tabular}

Ranking and weighting these main and sub-factors as shown in Tables 10-12 reveal the findings regarding barriers of adopting BIM for industrialized building construction:

(1) Among the multiple barriers to the implementation of BIM for building industrialization, the in- fluence of the financial factors (B) is the highest. Among the sub-factors related to financial investments, the high cost of BIM software, uncertainties on ROI, and the lack of benefits brought by BIM are ranked at 1 st, 4 th, and 1 st respectively indicating that capital play an important role. The 
purpose of the business is to make profits, so funding issues will become a key factor affecting the implementation of BIM. In order to enhance BIM application, governmental authorities could provide certain subsidies to projects that adopt BIM. Enterprises could organize experts to effectively evaluate the investment risk and return of using BIM. The proper adoption of BIM can be measured by shortened project cycle, improved project quality, increased efficiency, and the transformation at organizational level towards digitalization.

(2) Stakeholder-related factors of BIM implementation barriers in the context of building industrialization are only next to financial factors. They include the lack of senior management support, poor collaboration among project participants, and the lack of experience in using BIM, which are ranked at 5th, 6th, and 9th respectively. Multiple stakeholders including owners need to fully consider the pros and cons of BIM with forwardthinking of the communication between the owner and other project participants is critical. Contracting with specified roles and responsibilities in BIM for different stakeholders would be important to promote BIM adoption in industrialized construction projects.

(3) In the context of building industrialization, employee-related factors of BIM implementation are mainly due to the lack of skilled personnel and lack of proper training on BIM. Among them, lack of skilled personnel is ranked third. The development of both BIM-related software and hardware is relatively slow in countries like China. There is also a lack of practitioners who apply BIM for prefabricated construction projects. By promoting the study and application of BIM in the higher education, students' cognition and interest in BIM can be nurtured and their initiative in BIM can be cultivated. Lack of relevant training is ranked at seventh. Organizations could utilize BIM education and training as the career development opportunities for their employees, and also as the path towards organizations' digital transformation along with China's national momentum of promoting prefabricated construction.

(4) Factors of BIM implementation barriers related to external environment are mainly due to the facts that relevant laws and regulations have not been well-established. Governmental authorities are suggested to play a more significant role in promoting BIM in the construction market from multiple perspectives, including: standardizing how BIM can be engaged across the project life cycle; and legislation to secure the intellectual property and digital asset ownership.

(5) Factors of BIM implementation barriers related to software were perceived with relatively low significance. The incomplete modeling functions of BIM software was ranked $15^{\text {th }}$ among all sub-factors. Bridging the industry needs and software supplier with a unified national BIM standard would be vital to reduce unnecessary disputes. For example, some existing international BIM authoring tools for modeling lacked the optimization function for reinforcement of steel rebar, yielding many structural details unsatisfactory to end-users. Therefore, some software tools need to be continuously modified and improved to enhance its functionality. In some cases, integrating different BIM software tools will significantly enhance the efficiency in designing for manufacturing and assembly.

The current study provides more insights on promoting BIM especially amid the increasing practices of industrialized building construction towards off-site manufacturing and modularization of building products. Zhang et al. (2016) stated that financial factors should not be the most significant barriers of BIM implementation. $\mathrm{Xu}$ and Kong (2016) perceived that standardization and regulation are the major factor in promoting BIM for industry practice. This study did not completely agree with the prior research. Specifically, senior management support and financial investments are considered top critical factors. In fact, these factors are closely inter-related. With financial supports either at the organizational level or from governmental incentives, senior management would be more supportive, and vice versa. The differences of findings from this study could be due to the nature of industrialized building construction, as differing from the traditional in-situ construction when BIM is engaged. Industrialized projects, due to its special workflow and construction techniques, tend to require more rigorous coordination, communication, and collaboration among stakeholders from a more diverse background (e.g., manufacturer of modular components). Since the research, development, and practices of industrialized buildings are still in the early stage in China with continued momentum, this study would lead to more future work in integrating digitalization for prefabricated construction.

\section{Conclusions}

Prefabricated building has become one of the hotspot issues in the construction industry worldwide including China, one of the largest construction markets. However, there are still various challenges encountered during the implementation of prefabricated buildings. BIM, as the emerging digital technology, together with its concept and application, provides a method for reducing the fragmentation of construction supply chain and a better management platform for prefabricated building construction.

Based on inputs of industry professionals from China's construction sector, this study argued that BIM adoption for industrialization of building construction are highly dependent on capital and the support from owners and senior management. Relevant skills and knowledge are also critical factors. In addition to the governmental policy 
support for BIM, it is also recommended that companies could organize experts to effectively evaluate the risks involved in BIM uptake. More suggestions are provided related to organizational transformation in the journey towards digital-driven building industrialization, including but not limited to the legislation and regulation for intellectual properties of digital assets. At the same time, government and enterprises could provide practitioners with more learning opportunities for them to reduce BIM startup costs. In addition, by making full use of benefits of BIM, project information can be more reliably transmitted and shared among stakeholders. With connected data and information driven by BIM, the design, construction and other parties can effectively collaborate at all stages of an industrialized building construction project.

BIM and industrialized building construction are gaining momentum of being integrated to each other for enhanced productivity and sustainability worldwide. This study weights the factors of implementing BIM under the context of industrialized building projects. Although this study was conducted in China, the factors and suggestions of adopting BIM for building industrialization could be implied in the global construction industry. More case studies can be investigated in future research for demonstrating how the identified barriers could be overcome in implementing BIM for prefabricated construction. For example, the digital library of modular components could be established for wider application of off-site manufacturing for construction, involving design for manufacturing and assembly.

\section{Acknowledgements}

The authors wish to acknowledge the financial support of "Ningbo Transportation Technology Project (No. 202007)" and "Zhejiang Construction Technology Project (2019K060)".

\section{Author contributions}

Ping $\mathrm{Wu}$ and Yiting Dong conceived the study and were responsible for the design and development of the data analysis. Yidong $\mathrm{Xu}$, Feng Lin and Zhihong Pan were responsible for data collection and analysis. Feng Lin and Ruoyu Jin were responsible for data interpretation. Ping $\mathrm{Wu}$, Yidong $\mathrm{Xu}$, and Ruoyu Jin wrote the first draft of the article.

\section{Disclosure statement}

Authors in this paper confirm that they do not have any competing financial, professional, or personal interests from other parties.

\section{References}

Abubakar, M., Ibrahim, Y., Kado, D., \& Bala, K. (2014). Contractors' perception of the factors affecting Building Information Modelling (BIM) adoption in the Nigerian construction in- dustry. In Computing in civil and building engineering (2014) (pp. 167-178). https://doi.org/10.1061/9780784413616.022

Ahmed, S. (2018). Barriers to implementation of building information modeling (BIM) to the construction industry: a review. Journal of Civil Engineering and Construction, 7(2), 107-113. https://doi.org/10.32732/jcec.2018.7.2.107

Ahmed, S. M., Emam, H. H., \& Farrell, P. (2014). Barriers to BIM/4D implementation in Qatar [Conference presentation]. The 1st International Conference of CIB Middle East \& North Africa Conference, Abu Dhabi, United Arab Emyrates.

Arayici, Y., Coates, P., Koskela, L., Kagioglou, M., Usher, C., \& O'reilly, K. (2011). Technology adoption in the BIM implementation for lean architectural practice. Automation in Construction, 20(2), 189-195.

https://doi.org/10.1016/j.autcon.2010.09.016

Azhar, S. (2011). Building information modeling (BIM): Trends, benefits, risks, and challenges for the AEC industry. Leadership and Management in Engineering, 11(3), 241-252. https://doi.org/10.1061/(ASCE)LM.1943-5630.0000127

Babič, N. Č., Podbreznik, P., \& Rebolj, D. (2010). Integrating resource production and construction using BIM. Automation in Construction, 19(5), 539-543.

https://doi.org/10.1016/j.autcon.2009.11.005

Ballantyne, R., Packer, J., \& Falk, J. (2011). Visitors' learning for environmental sustainability: Testing short- and long-term impacts of wildlife tourism experiences using structural equation modelling. Tourism Management, 32(6), 1243-1252. https://doi.org/10.1016/j.tourman.2010.11.003

Bonett, D. G., \& Wright, T. A. (2015). Cronbach's alpha reliability: Interval estimation, hypothesis testing, and sample size planning. Journal of Organizational Behavior, 36(1), 3-15. https://doi.org/10.1002/job.1960

Chan, C. T. (2014). Barriers of implementing BIM in construction industry from the designers' perspective: A Hong Kong experience. Journal of System and Management Sciences, 4(2), $24-40$.

Chan, D. W., Olawumi, T. O., \& Ho, A. M. (2019). Perceived benefits of and barriers to Building Information Modelling (BIM) implementation in construction: The case of Hong Kong. Journal of Building Engineering, 25, 100764. https://doi.org/10.1016/j.jobe.2019.100764

Chunxia, Z. (2011). Study on application situation and development barriers of BIM in China construction industry. Construction Economy, 9.

Crotty, R. (2013). The impact of building information modelling: transforming construction. Routledge.

https://doi.org/10.4324/9780203836019

Czmoch, I., \& Pękala, A. (2014). Traditional design versus BIM based design. Procedia Engineering, 91, 210-215. https://doi.org/10.1016/j.proeng.2014.12.048

Eadie, R., Odeyinka, H., Browne, M., McKeown, C., \& Yohanis, M. (2014). Building information modelling adoption: an analysis of the barriers to implementation. Journal of Engineering and Architecture, 2(1), 77-101.

Elagiry, M., Marino, V., Lasarte, N., Elguezabal, P., \& Messervey, T. (2019). BIM4Ren: Barriers to BIM implementation in renovation processes in the Italian market. Buildings, 9(9), 200. https://doi.org/10.3390/buildings9090200

Elmualim, A., \& Gilder, J. (2014). BIM: innovation in design management, influence and challenges of implementation. Architectural Engineering and Design Management, 10(3-4), 183-199. https://doi.org/10.1080/17452007.2013.821399

Enshassi, A., AbuHamra, L., \& Mohamed, S. (2016). Barriers to implementation of building information modelling (BIM) in 
the Palestinian construction industry. International Journal of Construction Project Management, 8(2), 103-123.

Enshassi, A., \& AbuHamra, L. A. (2017). Challenges to the utilization of BIM in the Palestinian construction industry. Proceedings of the 34rd ISARC (pp. 938-944). Taipei, Taiwan. https://doi.org/10.22260/ISARC2017/0130

Ganah, A., \& John, G. A. (2015). An overview of the feasibility of achieving level 2 building information modeling by 2016 in the UK. Journal of Civil Engineering and Architecture, 9(8), 885-894. https://doi.org/10.17265/1934-7359/2015.08.001

Gerges, M., Austin, S., Mayouf, M., Ahiakwo, O., Jaeger, M., Saad, A., \& El Gohary, T. (2017). An investigation into the implementation of Building Information Modeling in the Middle East. ITcon, 22, 1-15.

Gerrard, A., Zuo, J., Zillante, G., \& Skitmore, M. (2010). Building information modeling in the Australian architecture engineering and construction industry. In Handbook of research on building information modeling and construction informatics: Concepts and Technologies (pp. 521-545). IGI Global. https://doi.org/10.4018/978-1-60566-928-1.ch023

He, L., \& Chen, Y. (2013). The present and future of industrialization of construction. Project Quality, 2.

He, Q.-h., Qian, L.-l., Duan, Y.-f., \& Li, Y.-k. (2012). Current situation and barriers of BIM implementation. Journal of Engineering Management, 1, 12-16.

Hope, A., \& Alwan, Z. (2012). Building the future: integrating building information management and environmental assessment methodologies [Conference presentation]. First UK Academic Conference on BIM.

Hosseini, M., Namzadi, M. O., Rameezdeen, R., Banihashemi, S., \& Chileshe, N. (2016a). Barriers to BIM adoption: Perceptions from Australian small and medium-sized enterprises (SMEs) [Conference presentation]. The 40th AUBEA: Radical Innovation in the Built Environment.

Hosseini, M. R., Banihashemi, S., Chileshe, N., Namzadi, M. O., Udeaja, C., Rameezdeen, R., \& McCuen, T. (2016b). BIM adoption within Australian small and medium-sized enterprises (SMEs): an innovation diffusion model. Construction Economics and Building, 16(3), 71-86.

https://doi.org/10.5130/AJCEB.v16i3.5159

Ismail, N. A. A., Chiozzi, M., \& Drogemuller, R. (2017). An overview of BIM uptake in Asian developing countries. AIP Conference Proceedings, 1903, 080008.

https://doi.org/10.1063/1.5011596

Jianxin, Z. (2010). Study on barriers of implementing BIM in engineering design industry in China. Journal of Engineering Management, 24(4), 387-392.

Jordani, D. (2010). BIM and FM: The portal to lifecycle facility management. Journal of Building Information Modeling (JBIM).

Jung, Y., \& Joo, M. (2011). Building information modelling (BIM) framework for practical implementation. Automation in Construction, 20(2), 126-133.

https://doi.org/10.1016/j.autcon.2010.09.010

Kekana, T., Aigbavboa, C., \& Thwala, W. (2014). Building information modelling (BIM): Barriers in adoption and implementation strategies in the South Africa construction industry [Conference presentation]. International Conference on Emerging Trends in Computer and Image Processing, Pattaya, Thailand.

Khosrowshahi, F., \& Arayici, Y. (2012). Roadmap for implementation of BIM in the UK construction industry. Engineering, Construction and Architectural Management, 19(6), 610-635. https://doi.org/10.1108/09699981211277531
Kiani, I., Sadeghifam, A. N., Ghomi, S. K., \& Marsono, A. K. B. (2015). Barriers to implementation of building information modeling in scheduling and planning phase in Iran. Australian Journal of Basic and Applied Sciences, 9(5), 91-97.

Kiviniemi, A., Karlshøj, J., Tarandi, V., Bell, H., \& Karud, O. J. (2008). Review of the development and implementation of IFC compatible BIM. Erabuild.

Li, H., Ng, S. T. T., Skitmore, M., Zhang, X., \& Jin, Z. (2017). Barriers to building information modelling in the Chinese construction industry. Proceedings of the Institution of Civil Engineers - Municipal Engineer, 170(2), 105-115. https://doi. org/10.1680/jmuen.16.00059

Li, J., \& Yang, H. (2017). A research on development of construction industrialization based on BIM technology under the background of Industry 4.0. MATEC Web of Conferences (Vol. 100). https://doi.org/10.1051/matecconf/201710002046

Liao, L., \& Teo, E. A. L. (2019). Managing critical drivers for building information modelling implementation in the Singapore construction industry: an organizational change perspective. International Journal of Construction Management, 19(3), 240-256. https://doi.org/10.1080/15623599.2017.1423165

Liao, L., Teo, E. A. L., \& Chang, R. (2019). Reducing critical hindrances to building information modeling implementation: The case of the Singapore construction industry. Applied Sciences, 9, 3833. https://doi.org/10.3390/app9183833

Liu, B., \& Liu, W. (2015). Application status and obstacles research of BIM in domestic construction industry. Advanced Materials Research.

Liu, S., Xie, B., Tivendal, L., \& Liu, C. (2015). Critical barriers to BIM implementation in the AEC industry. International Journal of Marketing Studies, 7(6), 162. https://doi.org/10.5539/ijms.v7n6p162

Mahalingam, A., Yadav, A. K., \& Varaprasad, J. (2015). Investigating the role of lean practices in enabling BIM adoption: Evidence from two Indian cases. Journal of Construction Engineering and Management, 141(7), 05015006. https://doi.org/10.1061/(ASCE)CO.1943-7862.0000982

Matarneh, R., \& Hamed, S. (2017). Barriers to the adoption of building information modeling in the Jordanian building industry. Open Journal of Civil Engineering, 7(3), 325-335. https://doi.org/10.4236/ojce.2017.73022

Memon, A. H., Rahman, I. A., Memon, I., \& Azman, N. I. A. (2014). BIM in Malaysian construction industry: status, advantages, barriers and strategies to enhance the implementation level. Research Journal of Applied Sciences, Engineering and Technology, 8(5), 606-614.

https://doi.org/10.19026/rjaset.8.1012

Migilinskas, D., Popov, V., Juocevicius, V., \& Ustinovichius, L. (2013). The benefits, obstacles and problems of practical BIM implementation. Procedia Engineering, 57, 767-774.

https://doi.org/10.1016/j.proeng.2013.04.097

Namdeo, S. K., \& Rout, S. D. (2016). Calculating and interpreting Cronbach's alpha using Rosenberg assessment scale on paediatrician's attitude and perception on self esteem. International Journal of Community Medicine and Public Health, 3(6), 1371-1374.

https://doi.org/10.18203/2394-6040.ijcmph20161448

Newton, K., \& Chileshe, N. (2012). Enablers and barriers of building information modelling (BIM) within South Australian construction organisations. University of New South Wales Sydney, Australia.

Pan, J., \& Zhao, Y. (2012). Research on barriers of BIM application in China's building industry. Journal of Engineering Management, 1, 6-11. 
Park, K., \& Kim, K. (2017). BIM application and adoption in the UK housing sector. In Integrated Building Information Modelling (pp. 46-81). Bentham Science. https://doi.org/10.2174/9781681084572117010005

Qinghua, H., \& Jing, Z. (2012). Study on barriers of building information modeling application in building construction enterprises. Construction Technology, 22.

Santos, J. R. A. (1999). Cronbach's alpha: A tool for assessing the reliability of scales. Journal of Extension, 37(2), 1-5.

Shen, Z., \& Li, Y. (2015). Essence and connotation for construction in building industrialization in China. Progress in Steel Building Structures, 17(5), 1-6.

Stanley, R., \& Thurnell, D. (2014). The benefits of, and barriers to, implementation of 5D BIM for quantity surveying in New Zealand. Construction Economics and Building, 14(1). https://doi.org/10.5130/AJCEB.v14i1.3786

Tabachnick, B. G., Fidell, L. S., \& Ullman, J. B. (2007). Using multivariate statistics (Vol. 5). Pearson Boston, MA.

Tan, T., Chen, K., Xue, F., \& Lu, W. (2019). Barriers to Building Information Modeling (BIM) implementation in China's prefabricated construction: An interpretive structural modeling (ISM) approach. Journal of Cleaner Production, 219, 949-959. https://doi.org/10.1016/j.jclepro.2019.02.141

Thanki, S., Govindan, K., \& Thakkar, J. (2016). An investigation on lean-green implementation practices in Indian SMEs using analytical hierarchy process (AHP) approach. Journal of Cleaner Production, 135, 284-298. https://doi.org/10.1016/j.jclepro.2016.06.105

Thompson, D., \& Miner, R. G. (2006). Building information modeling-BIM: Contractual risks are changing with technology. http://www.aepronet.org/ge/no35.html

Ullah, K., Lill, I., \& Witt, E. (2019). An overview of BIM adoption in the construction industry: Benefits and barriers. In 10th Nordic Conference on Construction Economics and Organization (Emerald Reach Proceedings Series, Vol. 2, pp. 297-303). Emerald Publishing Limited. https://doi.org/10.1108/S2516-285320190000002052

von Both, P. (2012). Potentials and barriers for implementing BIM in the German AEC market: results of a current market analysis. https://www.irbnet.de/daten/kbf/kbf_e_F_2844.pdf

Wandahl, S., \& Ussing, L. F. (2013). Sustainable industrialization in the building industry: on the road to energy efficient construction management. In ICCREM 2013: Construction and Operation in the Context of Sustainability (pp. 177-187). https://doi.org/10.1061/9780784413135.017

Wang, J., Zhao, J., \& Hu, Z. (2016). Review and thinking on development of building industrialization in China. China Civil Engineering Journal, 49, 1-8.

Won, J., \& Lee, G. (2010). Identifying the consideration factors for successful BIM projects. Proceedings of the International Conference on Computing in Civil and Building Engineering, Nottingham, UK.

Wong, A. K., Wong, F. K., \& Nadeem, A. (2009). Attributes of building information modelling and its development in Hong Kong. HKIE Transactions, 16(2), 38-45. https://doi.org/10.1080/1023697X.2009.10668156

$\mathrm{Xu}$, Y., \& Kong, Y. (2016). Analysis of the influence factors of application and promotion of BIM in China. Journal of Engineering Management, 30, 28-32.

Xu, Y., Zeng, J., Chen, W., Jin, R., Li, B., \& Pan, Z. (2018). A holistic review of cement composites reinforced with graphene oxide. Construction and Building Materials, 171, 291-302. https://doi.org/10.1016/j.conbuildmat.2018.03.147
Yan, H., \& Demian, P. (2008). Benefits and barriers of building information modelling. Proceedings of the 12th International Conference on Computing in Civil and Building Engineering (ICCCBE XII) \& 2008 International Conference on Information Technology in Construction (INCITE 2008), Beijing, China.

Zhang, L., Li, Y., \& Gao, Y. (2013). Barriers and countermeasures of the BIM application in China. [Journal of Civil Engineering and Management], 30(3), 65-69 (in Chinese).

Zhang, J., Long, Y., Lv, S., \& Xiang, Y. (2016). BIM-enabled modular and industrialized construction in China. Procedia Engineering, 145, 1456-1461.

https://doi.org/10.1016/j.proeng.2016.04.183 